\title{
プラスチックスのざらつき摩耗について*
}

山口章三郎 $* *$ 大柳 康 $* * *$ 岩本 勝匡 $* * *$ 木元 英明 $* * *$

\section{On the Abrasion of Plastics}

by

\section{Yukisaburo Yamaguahi, Ko Oyanagi, Katsumasa Iwamoto and Hideaki Kimoto \\ (Kogakuin University, Tokyo)}

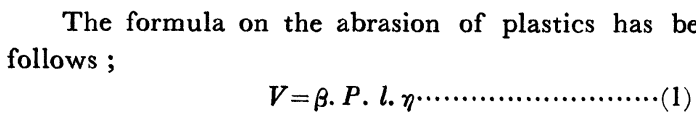

where $V$ is the total abrasion volume, $\beta$ abrasion coefficient and represented by the term, $\left(\frac{\alpha}{4 H_{c}} \cot \frac{\theta}{2} \cdot n^{2}\right), \quad P$ vertical load on the abrasion surface, $l$ abrasion distance, and $\eta$ abrasion efficiency. And $H_{c}$ is the scratch hardness number, $\alpha, \cot \frac{\theta}{2}$ and $n^{2}$ are the constants peculiar to each material and determined by the figure of scratched groove.

It has been proved that the formula (1) nearly corresponds to the results of the actual abrasion test which was carried out by using ASTM type's abrasion tester for several plastics, such as phenolic, polyester, acrylic, polystyrene, polycarbonate and nylon.

Generally, hardness number $H_{c}$ of thermosetting plastics is greater than that of thermoplastic material, but the values of the above constants, such as $\alpha, \cot \frac{\theta}{2}$ and $n^{2}$, for the thermosetting plastics are so greater than those for thermoplastic material, that the value of abrasion coefficient $\beta$ for thermosetting plastic becomes greater than that for thermoplastic material.

The effect of the grain size of abrasive $\mathrm{Al}_{2} \mathrm{O}_{3}$ on the abrasion efficiency, and of the relative speed between the surface of test piece and abrasive on the abrasion efficiency are also experimentally discussed respectively.

(Received Sep. 24, 1964)

\section{1 緒言}

筆者は，さきにプラスチックスの，その表面に粒状 の固体が圧力下にわいて相接し相対的に動く場合に生 ずる,いわゆるざらつき摩粍 (Abrasion) に関する実験 的考察を行ない，プラスチックスにおいては金属にお けるような摩耗量が単にかたざ，またはmodell 亿逆比 例するというような明快な結果が得られないととを報 告した.

本研究においては, 同じくプラスチックスのざらつ き摩耗に関して, その摩耗機構を理論的に解析し,さ らにその機構から引かきかたさとの関係を明らかにす るとともに，ての理論的結論を実験的に検討しようと する.

ついで，乙のざらつき摩耗試験方法において摩耗剂 の粒度, 摩摖速度などが摩耗量に与光る影響ならびに

* 原稿受付 昭和39年 9 月 24 日

** 正会 員 工学院大学 東京都新宿区角筈
摩耗中の試片の温度上昇度などを実験的に明らかにし ようとするものである.

\section{2 ざらつき摩耗の理論}

固体の粒子がプラスチックスの表面と他の表面との 間に介在して, 両面の相対的運動によって生ずるざら つき摩耗における一つの粒子について考元る．ての粒 子がプラスチックス表面に接している場合の代表例と して，Fig.1のような状態を想定する．すなわち鋭い 粒子の先端が，プラスチックスの表面を引かき去るて とによって摩耗が生ずると考元, ての粒子の先端の形 の代表例とて頂角 $r$ の錐形ダイヤモンドをとる，乙 の錐引か子が同図(a)の位置から, 表面に垂直な力 $P$ の下に横方向の力 $F$ が加光られることによって, (b) 図のようにし距離でけ引かかれたとする.

ての場合引かきによって生じたみぞの形は材料によ って必ずしも一様でなく，特に粘弾性的なプラスチッ クスにおいては相当異なった様相を呈する。一般的に はFig. 1 の(c)図に示すような断面を示し，もとの表面 

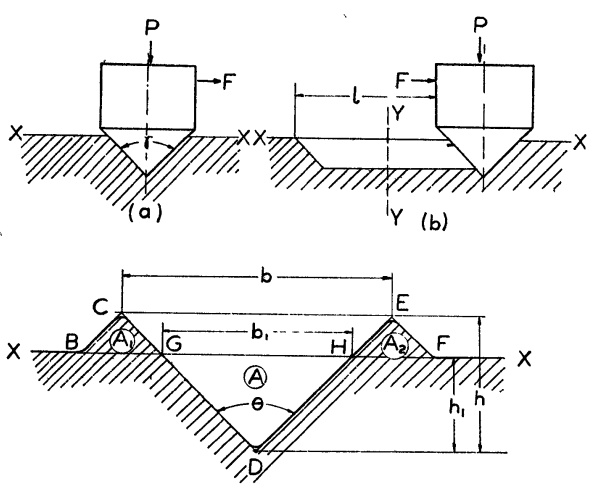

(c) Section $Y Y$

Fig. 1. Sections of scratched groove.

線 $X X$ の下にできたみぞの断面 $\Delta G D H(A)$ と，両側の表 面線から盛り上る部分の断面 $\triangle B C G\left(A_{1}\right)$ および $\triangle H E F$ $\left(A_{2}\right)$ を形成する*1.

したがって，円錐形引かき子によって，乙の表面か ら引き去られた真の断面積を $A_{0}$ とすると， $A_{0}$ はこの 材料の体積が変わらないという仮定においては,

$$
\begin{aligned}
A_{0} & =\{\Delta G D H-(\Delta B C G+\Delta H E F)\} \\
& =\left\{A-\left(A_{1}+A_{2}\right)\right\}
\end{aligned}
$$

となる。

いま引かいた距離をlとすると，引かき去られた容 積 $V_{0}$ は次式で表わされる.

$$
\begin{aligned}
V_{0} & =A_{0} l \\
& =\left\{A-\left(A_{1}+A_{2}\right)\right\} \cdot l .
\end{aligned}
$$

いま見かけのみぞの断面積 $A$ と真に引かき去られた 分の断面積 $A_{0}$ との比を引かき率 $\alpha$ とすると，

$$
\alpha=\frac{A-\left(A_{1}+A_{2}\right)}{A}
$$

となる。

$$
\begin{aligned}
& \text { したがって }, A-\left(A_{1}+A_{2}\right)=\alpha \cdot A \text { となるから } \\
& V_{0}=\alpha A l
\end{aligned}
$$

いま引かいたみぞの角を $\theta$ とすると，

$$
A=\frac{b_{1}}{2} \cdot h_{1}=\frac{b_{1}{ }^{2}}{4} \cot \frac{\theta}{2} \text { となり }
$$

また(c)図において， $b_{1} / b=h_{1} / h=n$ とすると， $b_{1}{ }^{2}=b^{2} n^{2}$ となる.

なお垂直圧力を $P$ とし，乙の材料の引かきかたさを $H_{c}$ とすると, $H_{c}=P / b^{2}\left(\mathrm{~kg} / \mathrm{mm}^{2}\right)$ であるから，*2

$$
\begin{aligned}
& b_{1}{ }^{2}=\frac{P}{H_{c}} n^{2} \\
& \therefore A=\frac{P}{4 H_{c}} \cot \frac{\theta}{2} \cdot n^{2} .
\end{aligned}
$$

したがって(3)と(4)式から $V_{0}$ は次式で表わされる.

*1 Fig. 14 参照

*2 投稿中. 山口章三郎ほか, 材料, 「プラスチックスの引かきか たさについて」

$$
V_{0}=\frac{\alpha}{4 H_{c}} \cdot \cot \frac{\theta}{2} \cdot n^{2} \cdot P \cdot l \cdot
$$

しかし実際の摩耗においては，摩耗剤の粉粒はての ような鋭い先端をもっていない.また同時に無数の多 くの粒子で支えられ，そのいずれもが常に先端を表面 に接しているわけでもないので, 垂直荷重のすべてが 個々の粒子の先端に有効にはかかってはいない.

いますべての摩耗粒子がFig. 1 のように鋭い先端を もち,かつ,いずれもが垂直に有効に立って，てろがる こともなく平行に引かくような場合の摩耗量と, 実際 の場合の摩耗量との比を摩耗効率 $\boldsymbol{\eta}$ とすると, 垂直圧 力 $P_{0}$ 引か き距離すなわち摩擦距離 $l$ に対する実際の摩 耗総量 $V$ は次式で表わされる.

$$
V=\frac{\alpha}{4 H_{c}} \cdot \cot \frac{\theta}{2} \cdot n^{2} \cdot P \cdot l \cdot \eta \cdots \cdots \cdots \cdots(6)
$$

いま $\left(\alpha \cdot \cot \frac{\theta}{2} \cdot n^{2} / 4 H_{c}\right)$ は材料による定数である として，てれを摩耗係数 $\beta$ とすると，

$$
\begin{aligned}
& \beta=\frac{\alpha}{4 H_{c}} \cdot \cot \frac{\theta}{2} n^{2} \ldots \ldots \ldots \ldots \ldots \cdots(7) \\
& \therefore V=\beta \cdot P \cdot l \cdot \eta \cdots \cdots \cdots \cdots \cdots \cdots \cdots \cdots(8)
\end{aligned}
$$

となる。

また単位圧力 $\left(\mathrm{kg} / \mathrm{cm}^{2}\right)$, 単位摩擦距離 $(\mathrm{km})$, 単位 摩擦面積 $\left(\mathrm{cm}^{2}\right)$ あたりの摩耗量 $\left(\mathrm{mm}^{3}\right)$ を比摩耗量 $V_{\boldsymbol{s}}$ $\left\{\mathrm{mm}^{3} /\left\{\left(\mathrm{kg} / \mathrm{cm}^{2}\right) \times \mathrm{km} \times \mathrm{cm}^{2}\right\}\right]$ すなわち $\left\{\mathrm{mm}^{3} /(\mathrm{kg}\right.$ ・ $\mathrm{km})\}$ とすると,

$$
\begin{aligned}
& V_{s}=\beta \cdot \eta \times 10^{6} \ldots \ldots \ldots \ldots \ldots \ldots \ldots \ldots \ldots(9) \\
& \therefore V=V_{s} \cdot P \cdot l \ldots \ldots \ldots \ldots \ldots \ldots \ldots \ldots \ldots(10)
\end{aligned}
$$

ともなる、ただし $(10)$ 式では $V$ は $\mathrm{mm}^{3}, P$ は $\mathrm{kg}, l$ は $\mathrm{km}$ とす.

\section{$3 \cdot 1$ 摩耗試験機}

\section{3 実験}

本実験に用いた摩耗試験機は，ASTM-D 1 242〜56 (1956) 亿定めたもので, 所定の円盤回転数 $N_{1}$ は 23 $\mathrm{rpm}$, 試片回転軸の回転数 $N_{2}$ が32rpmで，試片軸の円 盤軸の回りの直径 $d$ は $200 \mathrm{~mm}$ で, 円盤と試片との平 均相対速度すなわち摩擦速度は $\{(235 \pm 50) \pm 145\}=45$ $\sim 425 \mathrm{~mm} / \mathrm{sec}$, 平均 $235 \mathrm{~mm} / \mathrm{sec}$ となる。

\section{$3 \cdot 2$ 試験片}

摩耗試験片の形状は $75 \mathrm{~mm} \times 50 \mathrm{~mm}$ の矩形平面板で, 摩擦面積 $35.5 \mathrm{~cm}^{2}$, 試片軸の試片台に取り付け, 一定 摩擦距離 (実際には回転数)ごとに取りはずして, 天び んで科量して，その摩耗量を測定する.

実験に用いた各種プラスチックスの試験片の材料名 はTable I に示す.

また，試片の温度を測定するために，試片の表面か ら $5 \mathrm{~mm}$ 隔たったところに, サーミスター温度計感熱 部を挿入して，摩耗試験中の温度を測定した。

\section{3 -3 摩耗剂の粒度影響実験}


アルミナ $\left(\mathrm{Al}_{2} \mathrm{O}_{3}\right)$ の粉末を標準ふるいによって，次 のように選別した.

$$
\begin{aligned}
& 63 \text { メッシュ は 60〜65 メッシュ } \\
& 75 \text { メッシュ は 65〜85 メッシユ } \\
& 93 \text { メッシュ は 85〜100メッシュ } \\
& 160 \text { メッシュ は150〜170メッシュ }
\end{aligned}
$$

これらの各摩耗粉を用いて，同じ垂直荷重と摩擦速 度で, 各プラスチックスについて摩擦距離 $5.75 \mathrm{~km}$ ま で測定した。

\section{4 摩擦速度の実験}

上述の摩耗試験機の一部を改造して，円盤軸の回転

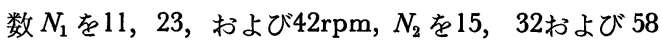
rpmの 3 段に変速できるよにして，摩耗剤の粒度を75
メッシュ，圧力を $4.5 \mathrm{~kg}$ でそれぞれ一定として各速度 について，各プラスチックにわたって上記摩耗試験を 行なった。なお摩耗試験ならびに試片の科量はすべて $20^{\circ} \mathrm{C}, 60 \%$ R.H.の恒温恒湿室で行なった.

\section{$3 \cdot 5$ 圧力の影響試験}

試験片に垂直にかかる圧力 $P$ が摩耗量に及ぼす影響 を実験するために，試片軸にかかる重錘を，所定のも の10 lbs $(4.5 \mathrm{~kg})$ のほかに $3.1 \mathrm{~kg}, 5.4 \mathrm{~kg}, 6 \cdot 7 \mathrm{~kg}$ およ び $9 \mathrm{~kg}$ のを作り, 各垂直荷重について，75メッシュ の摩耗粉で, 所定速度で, 数種のプラスチックスに関 して上記同様の摩耗試験を行なった。

\begin{tabular}{|c|c|c|c|c|c|c|c|}
\hline Mater ials & $\alpha$ & $H_{c}\left(\mathrm{~kg} / \mathrm{mm}^{2}\right)$ & $\theta^{\circ}$ & $\cot \frac{\theta}{2}$ & $n^{2}$ & $\begin{array}{c}\beta\left(\mathrm{mm}^{2} / \mathrm{kg}\right) \\
\left(\frac{\alpha}{4 H_{c}} \cot \frac{\theta}{2} n^{2}\right)\end{array}$ & $\begin{array}{c}V_{s} \\
\left(\mathrm{~mm}^{3} / \mathrm{kg} \cdot \mathrm{km}\right)\end{array}$ \\
\hline Phenolic & 0.82 & 33.7 & $111^{\circ}$ & 0.69 & 0.42 & $1.77 \times 10^{-3}$ & 264 \\
\hline Polyester & 0.66 & 16.2 & $95^{\circ}$ & 0.92 & 0.64 & $2.54 \prime$ & 320 \\
\hline Acrylic & 0.21 & 17.3 & $98^{\circ}$ & 0.87 & 0.49 & $1.50 \mathrm{~N}$ & 185 \\
\hline Polystyrene & 0.11 & 9.4 & $87^{\circ}$ & 103 & 0.41 & 1.2 & 159 \\
\hline Polycarbonate & 0.12 & 9.2 & $128^{\circ}$ & 0.49 & 0.32 & $0.41 "$ & 60.6 \\
\hline Nylon ' & 0.25 & 11.9 & $149^{\circ}$ & 0.27 & 0.24 & 0.32 & 21.2 \\
\hline
\end{tabular}

\section{3 - 6 摩耗係数測定試験}

Table I に示す各材料の試験片をマルテンス引かき

Table I. Values of section constants and specific abrasion volume of various plastics.

かたさ試験機を用い，頂角 $90^{\circ}$ のダイヤモンド円錐引

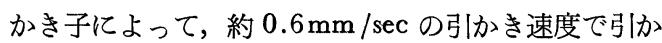
き，その引かきみぞの幅を顕微鏡で測定して，引か きかたさ $H_{c}$ を測定した．またての引かきみぞ部を鋭 利な刃物で切断し，その断面の顕微鏡写真をとって，

Fig. 1 亿示すような各部の寸法すなわち, $\theta, h, h_{1}$ なら びに $A, A_{1}, A_{2}$ の面積を測定して, 引かき率 $\alpha, n$ を 算出し,さらにこれらの数值から(7)式によって摩耗係 数 $\beta$ の值を求めた.

\section{4 実験結果亡考察}

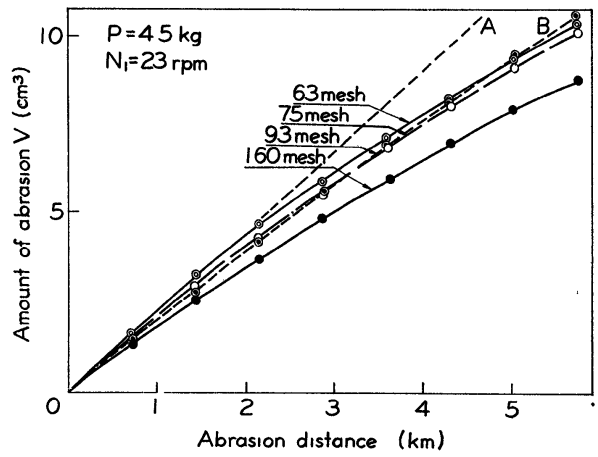

Fig. 2. Abrasion curves of polyester by various grain size of abrasive.

\section{4・1 摩耗剂の粒度の影饘}

3 種のプラスチックスについて，摩耗剤の粒度が 63 , $75 ， 93$ およ゙160メッシユのものをそれぞれ用いた場 合の摩耗試験の結果の一例としてポリエステルについ て示すと Fig. 2 になる，同図は垂直荷重 $4.5 \mathrm{~kg} ， N_{1}$ が

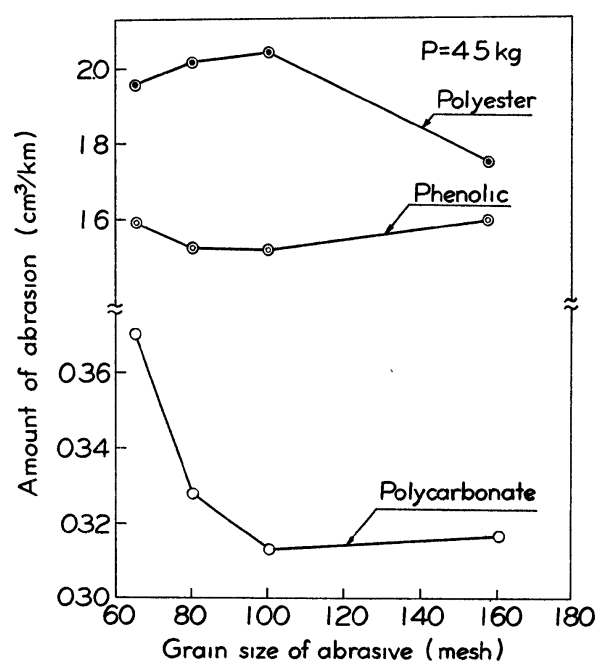

Fig. 3. Relations between grain size of abrasive and amount of abrasion. 
$23 \mathrm{rpm}$ の場合の摩耗量と摩擦距離との関係を表わす摩 耗䏣線を示す．他のプラスチックス，フェノールおよ びポリカーボネートについてもはぼ同椂の結果が得ら れた。

これらの結果をまとめて, 粒度と摩擦距離 $1 \mathrm{~km}$ あ たりの摩耗量との関係を示すとFig. 3 となる．同図か ら明らかなように,ての程度の範囲では,粒度の大きさ は摩耗量に著しい影響は与えないが，粒度が大きくな るといくぶん摩耗量が堌加するという傾向はみられる。

\section{2 摩擦速度の影辢}

試片表面と回転円般表面との相対速度がただちに摩 耗粉と試片表面との相対速度にはならないか，一応こ

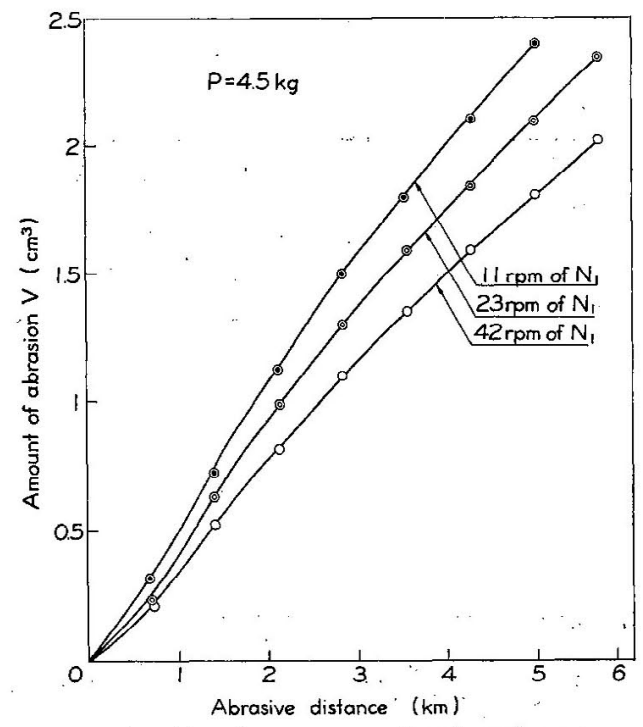

Fig. 4. Abrasion curves of polycarbonate at various speeds.

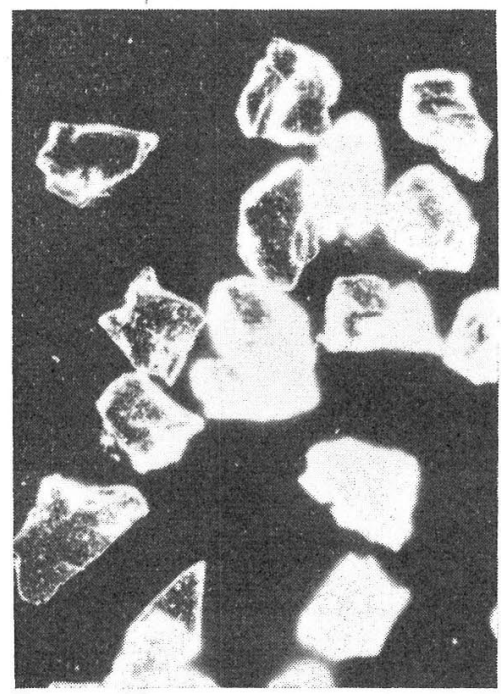

(a) New abrasive
こでは両表面間の相対速度を摩擦速度と考えることと する。

この場合も摩擦速度は，円般の回転周速度と試片の 自転による速度との相対速度となるから，試片，軸中 心部汃らの位置と回転の位置によって著しく変化を繰 返すわけであるが，てこではそれらの平均相対速度を もって摩擦速度とする。

この摩擦平均速度を前記 3 段の変速装置によって， 110，235 わ.よ゙ $420 \mathrm{~mm} / \mathrm{sec} の 3$ 段階に変えて，それ それれの速度について，ポリエステル，フェノール， ス チロールおよびポリカーボネートの試片を，垂直力と 粒度を一定の下で摩耗試験した結果のうち，代表例と してポリカーボネートの各速度に対する摩耗曲線を示 すと, Fig. 4 となる.他の試片についての同様な結果か ら,てれらの結果をまとめて, $1 \mathrm{~km}$ あたりの摩耗量と

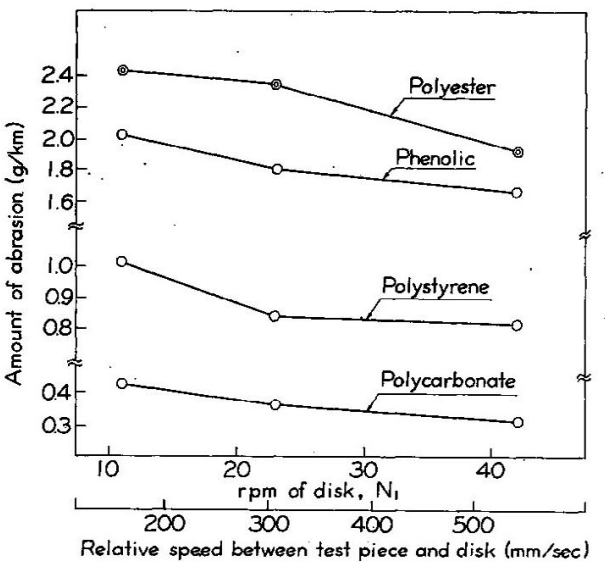

Fig. 5. Relations between amount of abrasion and friction speed for some plastics.

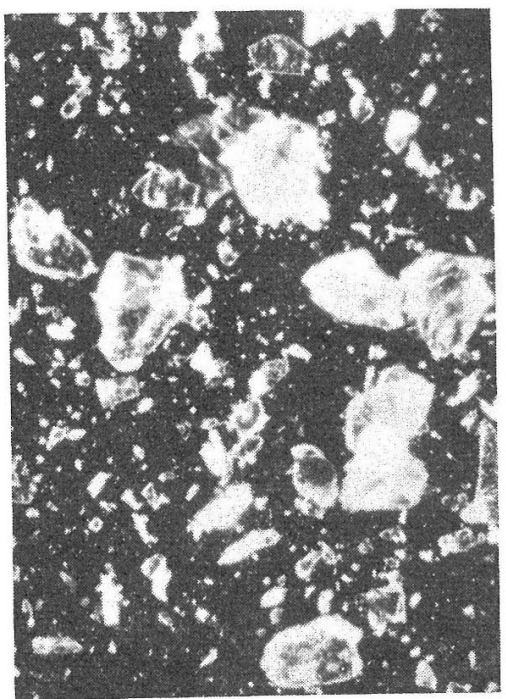

(b) Abrasive after testing abrasion of $5 \mathrm{~km}$

Fig. 6. Abrasive, $\mathrm{Al}_{2} \mathrm{O}_{3}$ powder. (Grain size of 93 mesh.) 
摩擦速度との関係を図示するとFig. 5 になる。同図か ら明らかなように，摩擦速度が大きくなるほど，1 kmあたりの摩耗量はわずかに減少する.

ての原因は，引かき試験において，引かき速さを大 きくすると，わずがみぞ愊が滅少し，引かきかたさ $H_{c}$ の值は大きくなるから ${ }^{* 8}$ 摩耗係数 $\beta$ の值分減少し て, 摩耗量が小さくなると考觉られる.

また摩耗係数 $\beta$ を一定引かき速度における一定值と 考完ると，摩擦速度を大きくすると摩耗効率 $ク$ がわず かに減少するとも考えられる。

\section{$4 \cdot 3$ 摩襟距離と摩耗量}

(6)または(8)式に示すように，理論的には摩耗量は摩 擦距離 l.飞正比例する. Fig. $2 ， 4$ および 7 亿示す各 摩耗曲線はいずれも直線とはならないで，摩擦距離が 大きくなるに従って下のほうに少しずつ曲がってくる. すなわち Fig. 2，7のOB曲線のようになり，理論式 と一致する $O A$ から少しはずれる。

ての原因として，摩擦距離が大きくなると表面が荒 れてくるととも考觉られるが,最も大きい原因は，本実 験においては摩耗剂を， $5.75 \mathrm{~km}$ の摩擦距離まで, 取 り替觉ず連続使用したため，Fig. 6 亿示すように相当 に摩擦距離を経過したもの(b)は，使用始めのもの(a)に 比べて，摩耗した切りくずが付着して，その先端の鋭 さを著しく阻害されるために，だんだん摩耗効率が減 じてくるのと考えられる。したがって，もし摩耗鼡 が同じ状態ならば， $O A$ 直線に一致して，理論式の上 うになると考えられる。

\section{4 垂直荷重と摩耗量}

(6)または(8)式に示すように，理論的には摩耗量は垂

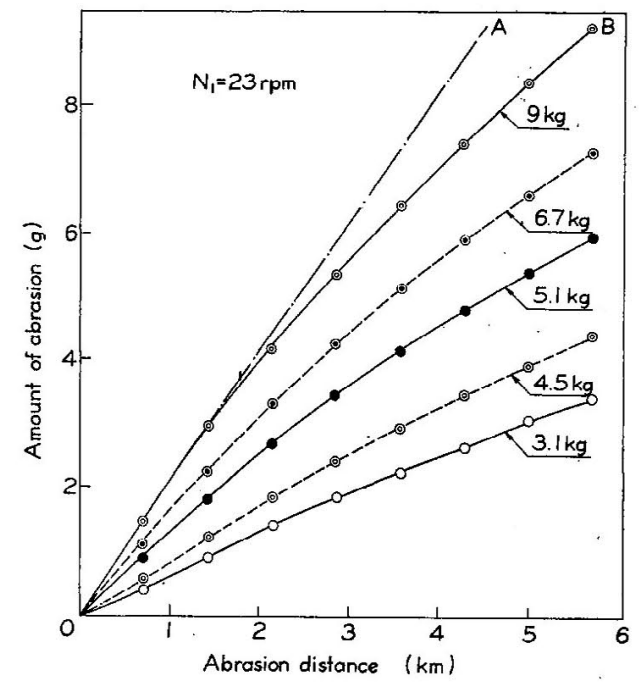

Fig.7. Abrasion curves of polystyrene under various vertical loads.

*3 投螎中. 山口章三郎, 材料, 「プラステックスの引かきかたさに つ大 $j$
直荷重 $P$ 亿正比例するとととなっているが，実験結果 は果してどうであろうか。

$P$ を 5 種の各荷重にして, 速度と摩耗剂の粒度を一

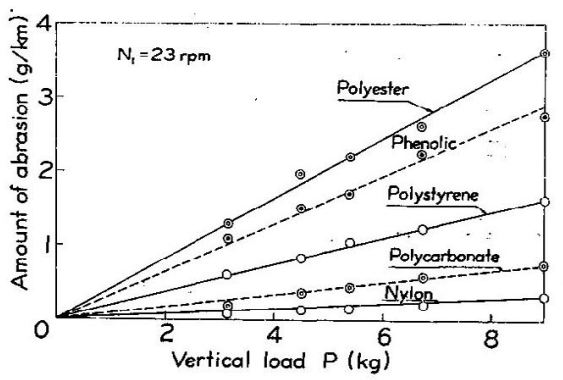

Fig. 8. Relations between amount of abrasion and vertical load for various plastics.

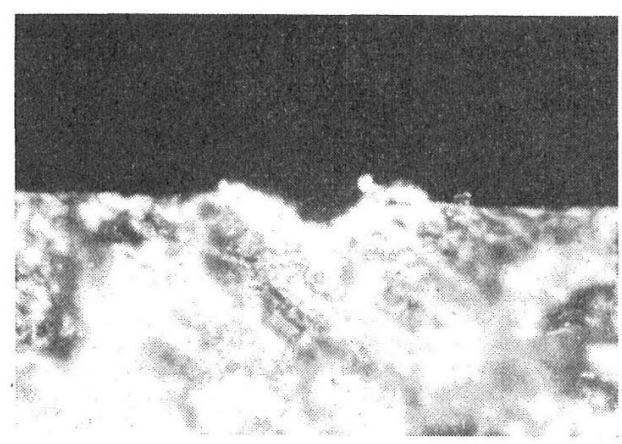

(a) Phenolic

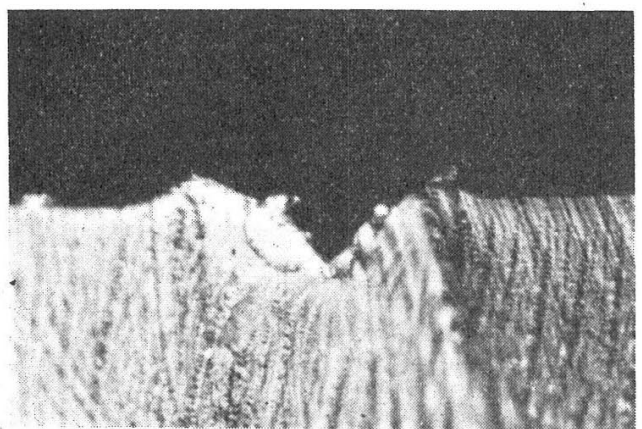

(b) Acrylic

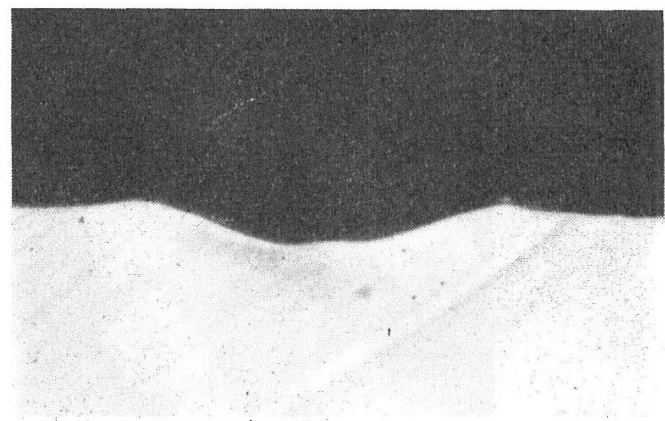

(c) Nylon 6

Fig. 9. Sections of scratched grooves. $(\times 560 \times 2 / 3)$ 
定にして，ポリエステル，フェノール，スチロール， ポリカーボネートおよびナイロンの 5 種のプラスチッ クス試片についての摩耗実験の中の代表例として, ス チロールに関する摩耗曲線を示すと Fig. 7 となる.

とれらの結果をまとめて, 垂直荷重量と単位摩擦距 離あたりの摩耗量 $(\mathrm{g} / \mathrm{km})$ との関係として表わすと， Fig. 8 になる. 同図から明らかなように，いずれのプ ラスチックスも両者の関係は直線的となり，上記の理 論式が実際に罗当することが認められる。

\section{$4 \cdot 5$ 摩耗係数と比摩耗量}

マルテンス引かきかたさ試験機による各プラスチッ クス試片の引かきかたさ $H_{c}$, および $90^{\circ}$ 円錐ダイヤ モンド引かき子によるみぞの断面顕微鏡写真例を示す Fig. 9 のような写真から求めた各形状因子 $\alpha, \theta, \cot$ $\frac{\theta}{2} お$ よ゙ $n^{2}$ の值を示すと, Table I の各欄の数值 となる.

またてれらの数値から(7)式によって摩耗係数 $\beta$ を求 めると同表の各値となる.

また標準試験状態 $\left(P=4.5 \mathrm{~kg}, N_{1}=23 \mathrm{rpm}\right.$, 摩耗剂粒度

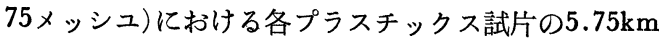
までの摩耗試験から求めた平均の $1 \mathrm{~kg}$ 荷重あたり, $1 \mathrm{~km}$ あたりの摩耗量すなわち比摩耗量 $V_{s}$ の值は図表 右端の欄の数値となる.

この $\beta$ と $V_{s}$ との関係を図示すると Fig. 10 となり， 少し大ざっぱにみて，両者の関係はほぼ正比例すると 考えることができ，(8)式が実験結果からも妥当である ことが認められる。

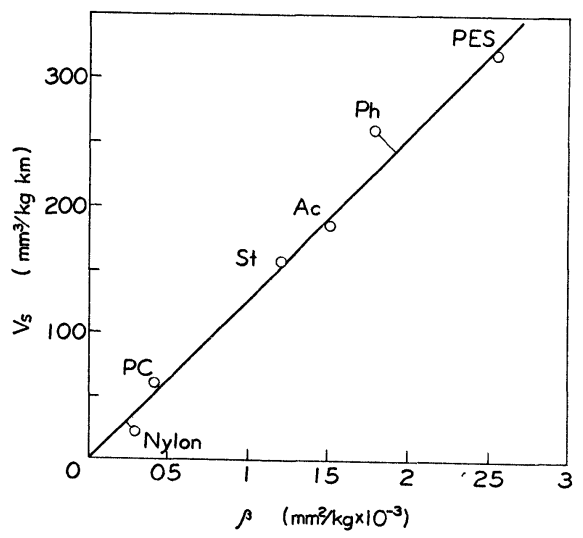

Fig. 10. Relations between abrasion coefficient $\beta$ and specific abrasion volume $V_{s}$.

\section{$4 \cdot 6$ 摩耗効率について}

(6)または(8)式における摩耗効率 $\eta$ を, 実験の結果か ら(9)式によって求めてみよう.

Table II の $\beta$ と $V_{s}$ の值のいずれの材料のものから でもよいが，いまFig.10の直線上にあるポリエステル
を代表例としてとると，(9)式から

$$
\eta=\frac{V_{s}}{\beta \times 10^{6}}=\frac{320}{2.54 \times 10^{-3} \times 10^{6}}=0.126
$$

すなわち摩耗効率は $12.6 \%$ となる。

\section{$4 \cdot 7$ 温度上昇について}

フェノール試片について，垂直荷重を $5.4 \mathrm{~kg} ， N_{1}$ を23rpm, 75メッシユの摩耗剂による摩耗試験におい ては，測定した試片の温度は，摩擦距離とともに上昇 し，4.5kmにおいて室温 $20^{\circ} \mathrm{C}$ より $4.2^{\circ} \mathrm{C}$ の温度上昇が 測定された。しかしての温度は表面から $4 \mathrm{~mm}$ 程度隔 たったととろの温度であり, 摩耗部分はこの温度より かなり高くなっているてとが推定される.

特にみぞの盛り上りの大きいナイロン，ポリカーボ ネートなどは, 表面の小さなたびたびの変形によって 温度は上昇すると考えられ，Fig.11亿示すように，温 度が高くなって，だれてきて横にはみ出した姿が，そ の断面の(a)，(b)のように見られる. ポリエステルのよ うに盛り上りの小さいものは，てのようなはみ出しが 見られないで(c)図のようになる。

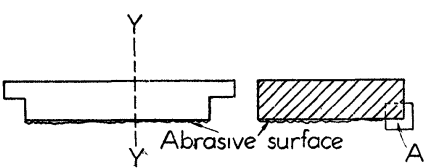

(1)

(2) Section $Y Y$

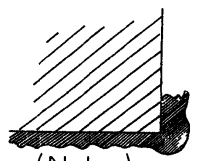

(Nylon)

(a)

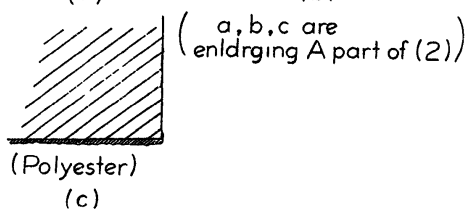

(c)

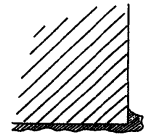

(Polycarbonate)

(b)
Fig. 11. Sectional figures of abrasive surfaces.

\section{$4 \cdot 8$ 総合的考察}

粘弾性的な性質を多分に有し，しかも摩耗試験中の 温度が，あるものはガラス転移点以上，あるものはそ れ以下，またあるものはちょうどその転移点上（たと えば4゚フッ化樹脂）にあるなど，また充てん剤を含む フェノール類など多彩なプラスチックス全般にっわた って，かたさだけを摩耗特性の因素とする考え方はあ まり簡単すぎたようである.

すなわち鋭い円錐形の引かき子による引かき試験に よってできたみぞの形を考察すると，各材料によって その形状は相当広い範囲にわたって異なっている。よ って真に引かき去られる断面積なるものを考え，ての 断面積 $A_{0}$ に引かき距離を乗じた容積をもって摩耗量と 
して，乙の $A_{0}$ を引かきかたさ $H_{c}$ と関係づけて数量的 に表わすものが摩耗係数 $\beta$ である．したがって いかえれば単位垂直圧力あたりの $A_{0}$ を表わすととと もなる。 この $\beta$ の值は $H_{c}$ には逆比例はするが， $H_{c}$ の值の変化範囲よりも， $\beta$ 亿関与する定数 $\alpha, \tan \frac{\theta}{2}$ および $n^{2}$ の各数值の変化範囲が特にプラスチックス においては大きいので， $H_{c}$ が摩耗特性全体に及ぼす 影響がより小さくなってしまった，一般に $H_{c}$ の小さ い材料のほうが上記諸定数がより小さいため $H_{c}$ の影 響を消してしまって余りがあり，やわらかい熱可塑性 材料のほうが，ちょうど飴の上を引かくように，みぞ の両側への盛り上りが大きく， $A_{0}$ すなわち $\beta$ 值が 小さくなって摩耗量が小さくなったわけである.

しかし実際の摩耗量と $A_{0}$ 亿よる理論的な摩耗との 比を表わす摩耗効率 $\eta$ の值は $12.6 \%$ で， $\beta$ の值で摩耗 全体を考えるととは，もとでの大きさで全身の大きさ を推定する感がしないでもない．

したがってざらつき摩耗においては，クの值に関与 する他の摩耗条件がなお考察されるべき余地として多 分に残っていると考えられる。

\section{5 結論}

以上を要約すると次のように結論される.

（1） 円錐引かき子による引かき試験から，ざらつ き摩耗式を誘導すると次式となる。

$$
V=\beta \cdot P \cdot l \cdot \eta
$$

ただし $V$ は摩耗量， $\beta$ は摩耗係数，Pは垂直圧力, $l$ は摩擦距離, $\eta$ は摩耗効率.

（2）摩耗係数 $\beta$ は引かきかたさ $H_{c}$ 亿逆比例し， その他の引かきみぞの形状を決定する定数によって定 まるが，プラスチックスにおいては $H_{c}$ の影響度より その他の定数による影響度が大きい。

（3）（1）の摩耗式は実験結果から検討して罗当と 認められる。

（4）摩耗剂の粒度が60～170メッシユにおいては, 粒度が大きくなるとわずかに摩耗量が減ずる傾向があ るが，その割合はわずかである。

（5）摩擦速度が増すほど，単位摩擦距離あたりの 摩耗量は少し減少する。

（付記） 本研究は昭和39年 5 月，日本材料学会第 13 期総会講演会で発表したものである.

本研究は昭和36年度文部省科学研究費の補助によっ たもので，実験を手伝っていただいた山口明男君，清 水誠一君に謝意を表する。

\section{参 考 文 献}

1) Oberle, T.L., J. Metals, 3, 438 (1951).

2）たとえば兽田範宗，潤滑，5，109（1960).

3) 山口章三郎, 合成樹脂, 8, No. 9, 22 (1962). 